\title{
Wêreldmededingendheid en die landbou*
}

\author{
J. van $\mathrm{Zyl}{ }^{* *}$ en H.D. van Schalkwyk \\ Departement Landbou-ekonomic, Universiteit van Pretoria, Pretoria, 0002
}

Aannaar 30 September 1996

\section{UITTREKSEL}

Teen die agtergrond van 'n veranderende ongewing wat markfaktore en groter wêreldhandel en mededinging toenemend die enigste maatstawwe van sukses word, is eerstens 'n raamwerk vir die onteding van wêreldmededingendheid ontwikkel. Dit word gevolg deur 'n hespreking van produktiwiteitsgroei in die landbou, asook 'n witeensefting van die rol van landbounavorsing. Derdens word prysfaktore en die ruilvoet bespreek, gevolg deur 'n bespreking van beleidsimplikasies. Die algemene gevolgtrekking is dat beide produktiwiteit en prysvenvantskappe in die landbousektor in 'n gunstige rigting beweeg, met die gevolg dat die Suid-Afrikaanse kommersiele landbousektor se wêreldmededingendheid hoog is. In teenstelling met die nywerheid kan slegs 'n klein minderheid landbouprodıkte goedkoper ingevoer word as watrvoor Suid-Afrikaanse produsente dit kan produseer; al word alle beskerming opgehef en ten spyte van relatief groot onderstenting an produsente in die meeste ontwikkelde lande. Die vooruitsigte vir die Suid-Afrikaanse landbou is gevolglik uilstekend.

\begin{abstract}
\section{World competitiveness and agriculture}

Against the background of a changing environment in which market factors and greater world trade and competitiveness are increasingly becoming the only criteria for success, a framework for the analysis of world competitiveness is initially developed. This is followed by a discussion on the growth of productivity in agriculure, as well as an exposition of the role of agricultural research. Thirdly. price factors and the terms of trade are discussed, followed by a summary of policy implications. The general conclusion is that both productivity and price relations in the agricultural sector are following favourable trends, with the result that the South African commercial agricultural sector is highly competitive. In contrast to the industry, only a small minority of agricultural products can be introduced locally at a price lower than that of South Africat producers, even if all protection is lifted and despite relatively extensive stuport given to producers in most developed countries. Consequenty, the prospects for South African agriculture are excellent.
\end{abstract}

\section{INLEIDING;}

Die wêreldmededingendheid van die Suid-Alrikaanse landbou was die afgelope aantal jare die onderwerp van verskeie studies. Kommer oor die toestand en toekoms van landbou, asook landbou se bydrac tot die Suid-Afrikanse ekonomie was meestal die motivering vir hicrdic studies. Hicrdic kommer is nic 'n nuwe verskynsel nie. Dit beklemtoon egter die wenslikheid on tendense gereeld te bestudeer ten einde verwikkelings te kan voorspel en verstaan. Slegs dan is gepaste en tydige remediërende optrede moontlik.

Dic kommersiële landbousektor sukkel reeds bykans twee dekades met probleme wat hul oorsprong het in die struktuur van dic Suid-Afrikaanse ekonomic. ${ }^{1}$ Hoewel dit oënskynlik blyk dat die relatief klein en steeds krimpende andeel van die landbouscktor in dic totale ckonomic decl is van 'n normale struklurele ekonomiesc ontwikkelingspatroon waar groci in dic industriële en tersiçre sektore dié in die landbou verbysteck, toon onlangse navorsing dat die ontwikkelingspatroon van landbou in werklikheid abnormaal is deurdat landhou ' $n$ veel kleiner rol speel - veral met betrekking tot werksverskalting - as wat 'n mens sou verwag van 'n land met Suid-Afrika se hulpbronbeskikbaarheid. ${ }^{2.3}$

Hicrdic afwykings of distorsics, naamlik relaticf swak groci in totale faktorproduktiwiteit en hoë kapitaalintensiteit ten spyte van algemene werkloosheid, is nie beperk tol die landbou nie, maar kenmerk die hele ekonomie. Desnieleenstaande is distor-

" Referaat gelewer by die jaarvergadering van die Suid-Afrikaanse Akademie vir Wetenskap en Kuns oor "Wêreldmededingendheid", Universiteit van Pretoria, 21 Junie 1996.

**m Outeur aan wie korrespondensie gerig kan word. 
sies in die landbou besonder verreikend as gevolg van 'n lang geskiedenis van volgehoue regeringsinmenging in die landbou. Dit het buitensporige toenames in meganisasic en plaasgrootte, asook alnames in arbeiders, gestimuleer. Ilierdie hesluile was rasioneel, tegnies doeltreffend en winsgewend vir die boere, maar verminder ekonomiese doelt relfendheid en gee alanleiding tot groot sosiale kostes. Verskeic navorsers kom tol die gevolgIrekking dat Suid-Alrikaanse landbou sy volopste hulpbron, naamlik arbeid, suboptimalal aanwend. Lae, gesubsidieerde rentekoerse en verskeic belastingtoegewings het die oormatige substitusic van arbeid met kapitaal aangemoedig.

Ten spyte hiervan het die landbou egter steeds die kwynende Suid-Alrikaanse ekonomic tydens dic afswaai in die 1970's ondersteun. Met die algemene goeie reêns van dié dekalde, het boere, wat sells in normale jare meer produseer as wat die behoefte binnelands is, hulle uitvocre substansieel begin verbeter. Die komparatiewe voordeel van die landbousektor is egter, relatief tot ander sektore in dic Suid-A frikalanse ckonomic, gec̈rodecr deur inflasic in die 1970's en 1980's. ${ }^{4.56}$ Die Jacobskomitec kom byvoorbeeld tot die gevolgtrekking dat die finansiële posisie van boere verswak weens stygende kostes en hoër risiko's in boerdery en dat dit in likiditeitsprobleme eindig.?

Die vraag wat nou ontstaan, is hoe die Suid-Afrikaanse landbou se wêreldmededingendheid tans daar uitsien, gegewe die geskiedenis van staatsondersteuning en 'n veranderende omgewing waar markfaktore en groter wêreldhandel en mededinging toenemend die enigste maatstawwe van sukses is. Teen hierdic agtergrond word 'n raamwerk vir dic ontleding van wêreldmededingendheid eerstens ontwikkel. Dit word gevolg deur 'n bespreking van produktiwiteitsgroci in dic landbou, asook ' 11 uitcensetting van die rol van landbounavorsing. Derdens word pryslaktore en die ruilvoet bespreek. 'n Aantal gevolgtrekkings sluit die referaat af. Die landbousektor as geheel is die onderwerp van bespreking. Individuele bedrywe se situasies verskil egter beduidend.

\section{2. 'N RAAMWERK VIR DIE ONTLEDING VAN MEDE- DINGENDHEID}

'n Onderneming of ekonomicse sektor se finansiële prestasie is die resultaat van interaksies van 'n groot aantal beheerbare en nicheheerbare faktore. 'n Bestuurder (of sektor) probeer om finansieel so goed moonlik te presteer deur die toewysing en aanwending van bronne walaroor hy/sy beheer het binne 'n omgewing bepaal deur onbeheerbare faktore. Dic volgende tipies beheerbare faktore word onderskei:" (1) die gebruik van nuwe produksietegnologie; (2) hulpbronsubstitusic; (3) opleiding en motivering van werkers; en (4) bate-ontplooiing en vervanging. Tipies niebeheerbare laktore sluil aspekte in soos: (1) die ckonomiese omgewing (wissclkoerse, rentekocrse, beleid, cns.); (2) klimaal; (3) markgroci of -af hame; (4) stygende insetpryse (arbeid, kapitaal items, intermediêre insetıe, ens.); en (5) verskillende inflasickoerse vir uitset- en insetpryse.

Onbehecrbare faktore kan 'n belekenisvolle positiewe of negatiewe invloed op die bedryf se winsgewendheid, en dus ook mededingendheid, uilocfen. Dit is egter moontlik om die invloed van hierdic faktore op mededingendheid eksplisiet to bepaal, asook hoe verskillende strategieë en beleide winsgewendheid verhoog of verlaag. Dic bronne van tocnames en af names in mededingendheid van die landbou word vervolgens ontleed.

Konvensionele finansiêle analise toon dat wins bepaal word deur die verskil lussen inkomste en koste (kyk figuur la). Gesonde verstand dikteer daarom dat inkomstes vinniger as kostes moet toeneem. Die basis van alle sektore of lirmas se inkomstes en kostes is egter netwerke van beheerbare en niebeheerbare faktore, gevolglik verskal die blote monitering van inkomstes en kostes nie insig in die interaksies van die onderskeic faktore nic - interaksies wat uitcindelik aanleiding gee tot mededingendheid. Dit is egter moontlik om uit diesellide basiese rekeningkundige inligting wiarmee inkomstes en kostes bereken word daardie faktore wat mededingendheid beïnvloed, te identifiseer (sien liguur la-e).

In die bestudering van die boonste ry van figuur ib word produkhoeveclheid (uitsel) en hulpbronhoeveelheid (inset) geidentiliseer. In die elementêrste vorm is produktiwiteit die produkhoeveclheid gedeel deur hulphronhoeveclheid. Daar bestalan dus 'n unieke produkliwiteitsverwantskap vir elke hulphron wal in dic produksieproses gebruik word. 'n Scktor vall die ekonomic - of boerdery - ondervind 'n toentame in produkliwiteit as die produkhoeveclheid teen 'n vinniger koers loeneem as die hulpbronhoeveclheid wat in die produksieproses gebruik word (of' $n$ afname indien die omgekeerde plaasvind) (kyk figuur le). Met alle ander faktore konstant. het produktiwiteitsverhogings 'n direkte verhoging in wins en mededingendheid tot gevolg.

Daar bestain 'n soortgelyke verwantskap tussen produkpryse en hulpbronpryse, naamlik die ruilvoet of prysuerwantskap wat deur die produkprys/hulpbronprys-verhouding verteenwoordig word. Insgelyks bestaan daar 'n unieke prysverwantskap vir elke hulpbron of insel in 'n bepaalde sektor. Indien produkpryse vinniger as hulpbronpryse styg, is die resultaat 'n gunstige prysverhouding. Met alle ander faktore konstant. lei 'n gunstige prysverhouding direk tot groter winste en mededingendheid. 'n Nadelige prysverhouding is die gevolg van hulpbronpryse wat vinniger styg as produkpryse. Dil lei direk tot 'n daling in winste en gevolglik mededingendheid met alle ander faktore konstant.

In plaas van konvensionele winsontleding, soos verteenwoordig deur dic middelste ry van figuur $1 d$, behoort wins en mededingendheidsveranderings eerder beskryf te word as die resultaat van veranderings in produktiwiteit en die prysverwantskap, soos verteenwoordig deur die middelste kolom van liguur ld. Dit is dan ook die doel van hierdie referaat om die effek van hierdie faktore op mededingendheid van nader te heskou.

Veranderings in produktiwiteit word deur twee duidelik onderskeibare en meetbare komponente beinvloed, naamlik verandering in kapasiteitsbenutting en 'n verandering in doeltreffendheid. Beter kapasiteitsbenutting ontstaan tipies wanneer produksic verhoog, terwyl sekere hulphronne konstant gehou word. Produktiwiteitsverhoging volg omrede produksie per eenheid vaste hulpbron styg. Verandering in doeltreffendheid is die ander laktor wat produktiwiteit kan beïnvloed. Groter doeltreffendheid word verkry wanneer hulphronhocveelhede per eenheid geproduseer minder word. Toenames in doeltreffendheid is dikwels die gevolg van nuwe tegnologie, opleiding of die substitusic van hulpbronne. Produktiwiteit verskaf' n belangrike maatstaf van mededingendheidsprestasie indien beheerbare bydracs tot doeltreftendheidsveranderings onderskei word van die nicheheerbare bydraes.

Figuur le illustreer die meetbare bronne van veranderinge in mededingendheid van 'n besigheid of scktor, in hierdie geval die landboubedryl. Soos winste en mededingendheid van jaar tot jaar verander, kan gemeet word tot watter mate toenames die gevolg is van veranderings in doeltreffendheid en/of prysverwantskappe. Binne hierdic raamwerk kan mededingendheid verhoog word deur produktiwiteitsgroei of gunstige prysverwantskappe of ' $n$ kombinasie van beide. Die pad tot mededingendheidsverhoging het egter belangrike gevolge vir die langertermyn mededingende posisionering van 'n bedryf. 
3. PRODUKTIWITEITS(FROEI IN DIE SUID-AFRIKAANSE KOMMERSIËLIE I.ANDBOU

Landbouproduktiwiteitstatistick vergelyk landbou-inselte met uitsette om die prestasie van die sektor te meet. Die twee belangrikste metodes van produktiwiteitsmeling is parsiële en multifaktorproduktiwiteitsanalise. Parsiële produktiwiteitsmaatstawwe verbind uitset mel 'n enkele inset, gewoonlik arbeid of grond, en gee sodoende groot betekenisvolheid an die gemiddelde lisiese produktiwiteit van 'n enkele laktor as 'n matstal van die tolale produkliwiteit van 'n hele proses. Dit neem egler nic die vinnige toename in nie-plaasinselle in berekening nie.

FIGUUR I(a)

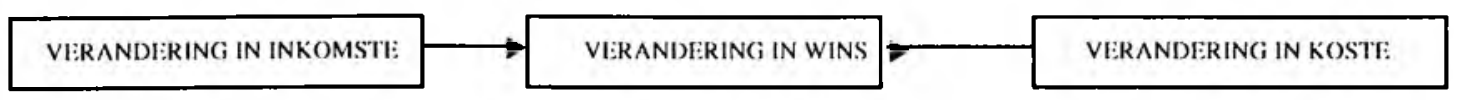

FIGUUR I(b)

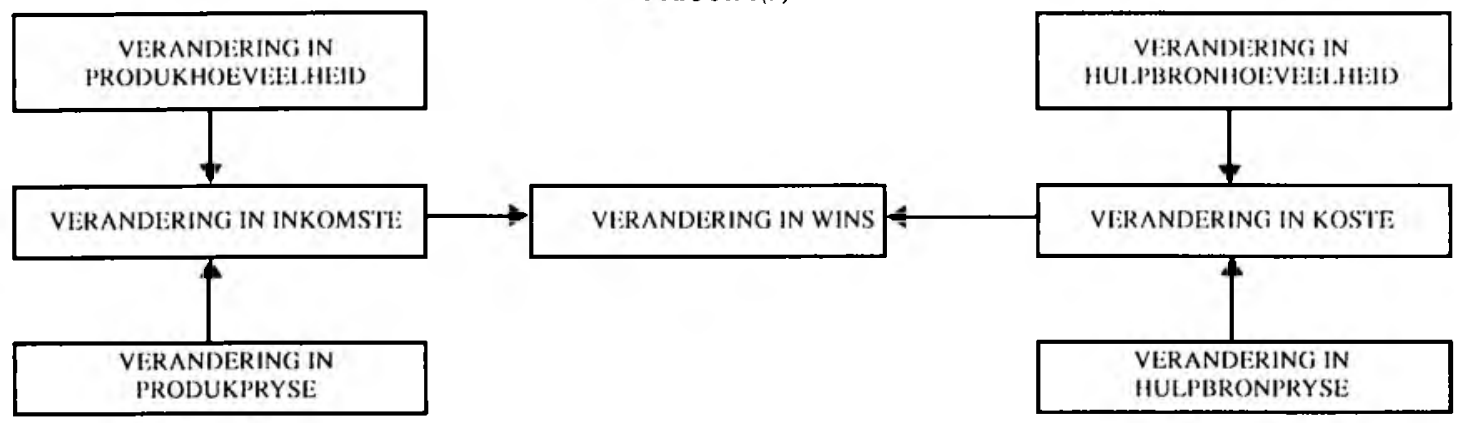

FIGUUR I(c)

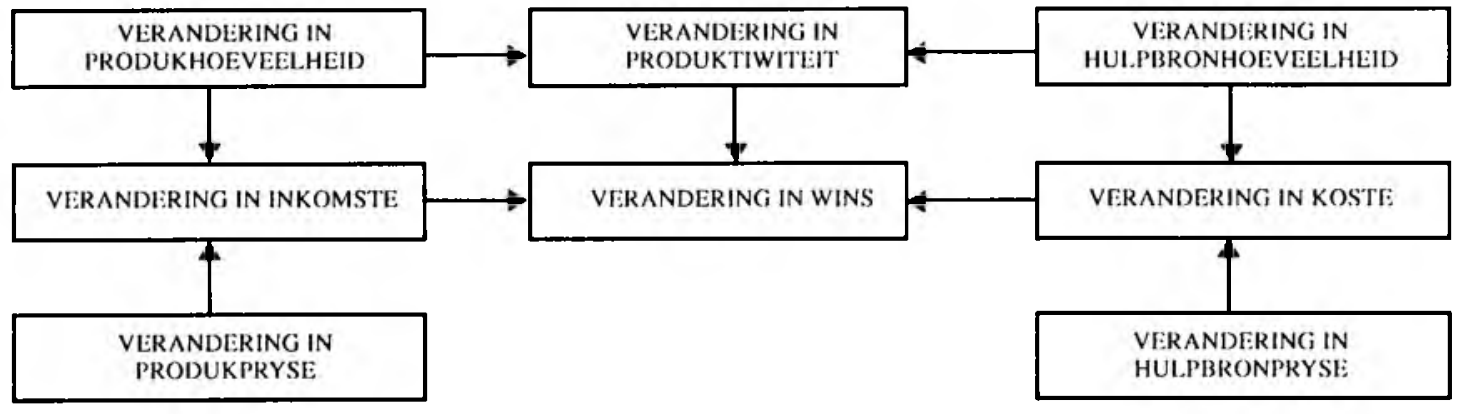

FIGUUR I(d)

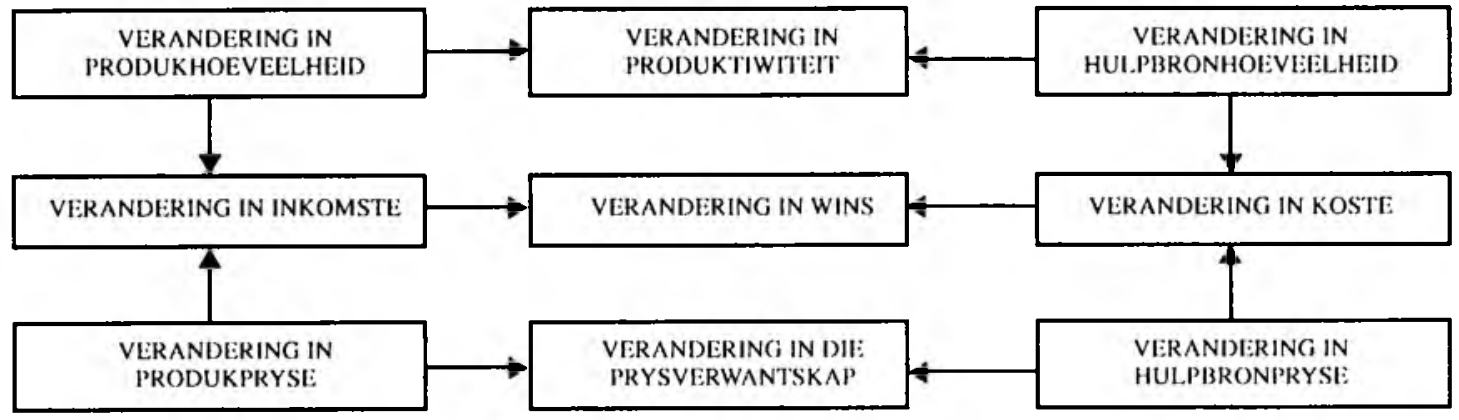

FIGUUR I(e)
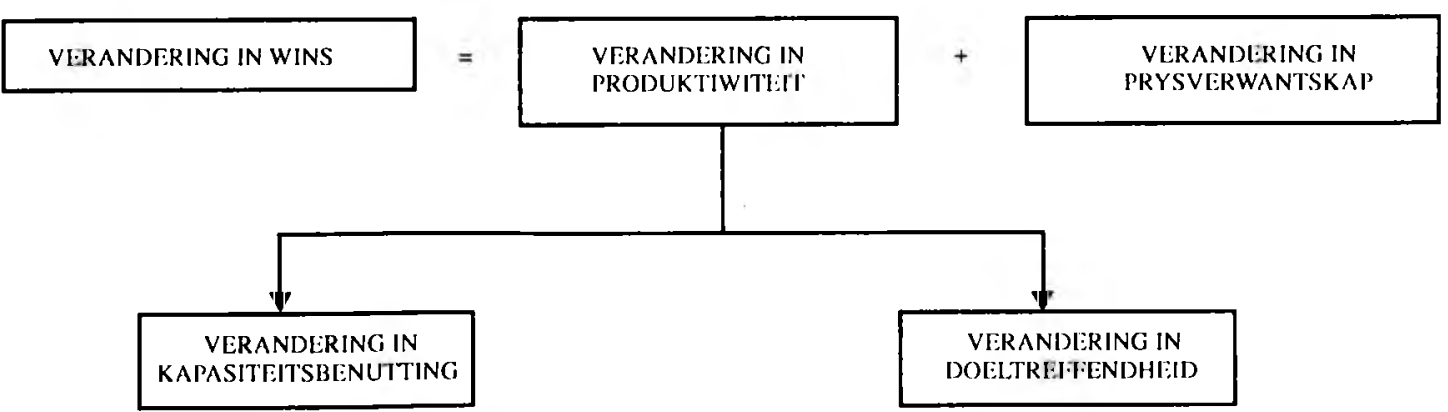
Om hierdie redes is dit 'n onbevredigende maatstaf' van totale produktiwiteit. Die verhouding van totale uitset tot 'n tolaal van alle insette gekombineerd, is 'n maatstal van totale faktorproduktiwitcit (TFP) ol multifaktor-produktiwitcit. TFP-maatslawwe van meervoudige-insel-produksieprosesse beskryl die totale koers van produktiwiteitsgroei as 'n enkele tydrecks. Dit is die onderwerp van 'n groot aantal studies wat nickonvensionele insette, soos navorsing en ontwikkeling (N\&O) en voorligtingsuitgawes inspan on TFP-groci te verklaar."

Twee metodes om die veranderinge in totale laktorproduktiwitcil te mect, word onderskei:") (a) dic tweestap-verdelingsmetode waar veranderinge in TFP-groei ecrs bereken word, en in 'n tweede stap verklalar word deur fak tore soos navorsing en ontwikkeling ( $\mathrm{N} \& \mathrm{O}$ ) en voorligting (hierdic metode is reeds gebruik vir ontleding van die Suid-Afrikaanse kommersiële landbou ${ }^{11,12}$ ); en (b) die gë̈ntegreerde benadering (watar die produktiwiteitsverhogende of kondisionerings aktore direk in 'n primale of duale voorstelling van produksic ingesluit word ${ }^{13}$ ). Die geintegreerde benadering, gebaseer op 'n dualal formulering van die produksiefunksie, het die voordeel dal dit beperkende declbaarheidsaannames minimaliseer, asook dal dic noodsiaklikheid van die aannames van volle statiese ewewig. Hicks neutrale tegniese verandering en konstante skaalopbrengs, wat implisiet is in die tweefase-benadering vermy word.

\subsection{Tolale faktorprodhktiwiteil}

Figuur 2 toon die resultaat van die totale laktorproduktiwiteitsberekenings vir die Suid-Afrikaanse landbou sederl 1947."

Die uitselindeks het sedert 1947 met meer as 350 persent teen 'n koers vall ongeveer 3,0 persent per jalar toegeneem. Die indeks van insette het meer as verdubbel, met 'n gemiddelde toenamekoers van 1,8 persent per jalar. Hierdie gemiddelde groeikoerse verskuil egter onderliggende tendense. Insette het byvoorbeeld tot 1980 teen 2,5 persent per jaar toegeneem, en daarna met byna 1,0 persent per jaar gedaal. Hierdie afname in insettoediening verklaar die toename in TFP gedurende die algelope dekade. Indien die hele periode egler geneem word, is die tocname in TFP relatiel laag: ongeveer I,3 persent per jaar. Dit is egter duidelik dat daar geen TFP-groei oor die periode 1947-65 was nie. Gedurende die periode 1965-81 he TFP toegeneem teen 2, 15 persent per jaar, terwyl die groeikoers sedertdien betreklik vinnig togeneem het teen amper 3,0 persent per jaar."

Die parsiële produktiwileitsindekse vir arbeid en grond groei onderskeidelik met 3,6 en 3.1 persent per jaar. Hierdic indekse word ingesluit omrede dil bekend is en ook omrede die konvensionele siening dat produktiwiteitsgroei met betrekking tol die primêre insette hoêr is as TFP-groei gestand gedoen word. Laatsgenoemde is die gevolg van die substitusic van grond en arbeid met nic-plaasinselte. ${ }^{\text {t }}$

Ten einde die onderliggende oorsake van die veranderings te verklatar, is dit nodig om in groter besonderhede na die komponente van die onderskeie indekse te kyk. Uitsette kan verdeel word in gewasse, luinbouprodukle en veeprodukle. Tuinbou het vinuiger as gewasse toegeneem, lerwyl veeprodukte stadiger as beide gegroei hel. Die relal iewe groeikoerse sedert 1947 beloop onderskeidelik 3, I (gewasse), 4,2 (tuinbou) en 2,4 (veeprodukte) persent per jaar. Die droogles van die 1980's word duidelik in die uitselindekse getoon, met veral gewasproduksie onder droëlandverbouing wat die ergste hieronder ly.

Soos reeds aangetoon, is primere insette gesubstitueer mel nie-plaasinsette. Die koste-alandecl van arbeid daal vanal 36 persent na slegs 15 persent, wat 'n negaliewe groeikoers vir arbeid van -0,6 oor die periode sedert 1947 verteenwoordig. Grond het sy koste-aandecl behou, maar geen groci getoon nic. Die totale toename in insettoedeling word gevolglik verteenwoordig deur die relaticf hoë grocikoerse in intermediêre insette (4,2 persent per jaar) en kapitaalgoedere ( 1,7 persent per jaar). Hierdie gemiddeldes vir die totale periode verskuil die onderliggende tendense. Intermediêre insette het 101980 teen meer as 5,0 persent per jaar toegeneem. en daarna met 0,2 persent per jaar gedaal; kapitaalinsette het tot 1982 met 2,5 persent per jaar toegeneem en sedertdien met meer as 3,0 persent per jaar gedaal.

Hierdie tendense kan as volg salamgeval word: Gedurende die periode lol 1970 is die bewerkle area onder droëland-miclieproduksie in die somersaaigebiede uitgebrei namate osse met trekkers vervang is. Groter areas kon bestuur word, en arbeidsgebruik het toegeneem, wat gedeeltelik te wyte is aan die gebruik van kunsmis en hoë-opbrengsvariëteite. Na 1970 was die effek van meganisasic oorheersend, veral as gevolg van dic meganisasic van dic oesproses wat dic swaar arbeidsalanvraag gedurende oeslyd verlig het. ${ }^{15}$ In dić opsig was die patroon in die somerreëngebiede slegs 'n nabootsing van dil wal reeds vroeër in dic winterreengebiede plaasgevind het, waar dic uitbreiding van dic bewerkte oppervlakte grootliks teen 1947 voltooi was. Dic proses is aangehelp deur 'n sosiale beleid wall dic mobiliteil van arbeiders (Paswelte) beperk hel, asook ander beleide wat goedkoop kapitial gesubsidiecrde krediet wat selfs negaticwe reèle rentekoerse, asook belastingtocgewings - insluit. Daar kan min twyfel wees dat hierdic distorsies en beleide gelei het tor die ongewenste substitusie van kapitaal vir arbeid, wat substansiële sosiale en ckonomiese kostes vir die breër gemeenskap tot gevolg gehad hel - veral met betrekking tot dic voortydige verlies aan werksgeleenthede in die landbousckır. ${ }^{\text {th }}$

FIGUUR 2: Insette, uitsette en totale faktorproduktiwiteit (TFP) in die Suid-Afrikaanse landbou (1947-1991). 


\subsection{Bydrae van navorsing, ontwikkeling en voorligting}

Die onderliggende redes vir die verandering in TFP in die SuidAlrikaanse kommersiële landbou word verklaar alan die hand van niekonvensionele insette soos plaaslike navorsing en ontwikkeling $(\mathrm{N} \& \mathrm{O})$, oorspoeleffekte van oorsese $\mathrm{N} \& \mathrm{O}$, voorligting, opleiding en klimaat. ${ }^{12,13}$

In dié verband is die bydrac van openbare $N \& O$ van spesificke belang. Die skaduprys van openbare N\&O-besteding is relatief laag tot ongeveer 1970, waarna dit toenemend sterk positief word. Die gevolg is dat 'n relaticf hoë marginale interne opbrengskoers van 44,25 persent per jaar op openbare N\&O verkry word vir die hele periode sedert 1947 (die differensiële koerse vir gewasverbouing, tuinbou en vecproduksie is onderskeidelik 29 persent, 98 persent en 4 persent per jaar). Hierteenoor is die vergelykbare opbrengskoerse vir voorligting relatief laag (kleiner as 5,0 persent). 'n Verwante aspek is die betekenisvolle invloed wat buitelandse N\&O op TFP-groci gehad het.

Die buitengewoon kort slocringsperiode met betrekking tot die effek van plaaslike N\&O op TFP-groci, hou verband met laasgenoemde verskynsel (kyk figuur 3 ). Dit blyk duidelik dat openbare landbounavorsing in Suid-Afrika hoofsaaklik gemik is op aanpassing van oorsese navorsing en tegnologic, beide biologies en meganies, vir plaaslike toestande. Ter stawing toon figuur 3 dat voordele uit openbare besteding aan N\&O in SuidAfrika na slegs dric of vier jaar 'n hoogtepunt bereik, terwyl geen betekenisvolle voordele na tien jaar behaal word nie. Hierteenoor is die ooreenstemmende periodes vir die VSA en Verenigde Koninkryk onderskeidelik meer as tien en twintig jaar.

\section{PRYSVERWANTSKAPPE IN DIE SUID-AFRIKAAN- SE LANDBOU}

Inflasie, soos gemeel deur dic algemene verbruikersprysindeks, was hoër as 10 persent gedurende die periode 1974-93. In hierdie tyd het pryse van landbou-insette en -uitsette nie proporsionecl toegeneem nie. Voor 1968 was inllasiekoerse relatief laag. Die periode 1968-73 is gekenmerk deur matige inflasie met groter stygings in produk- as in insetpryse. Sedert 1974 het hoë

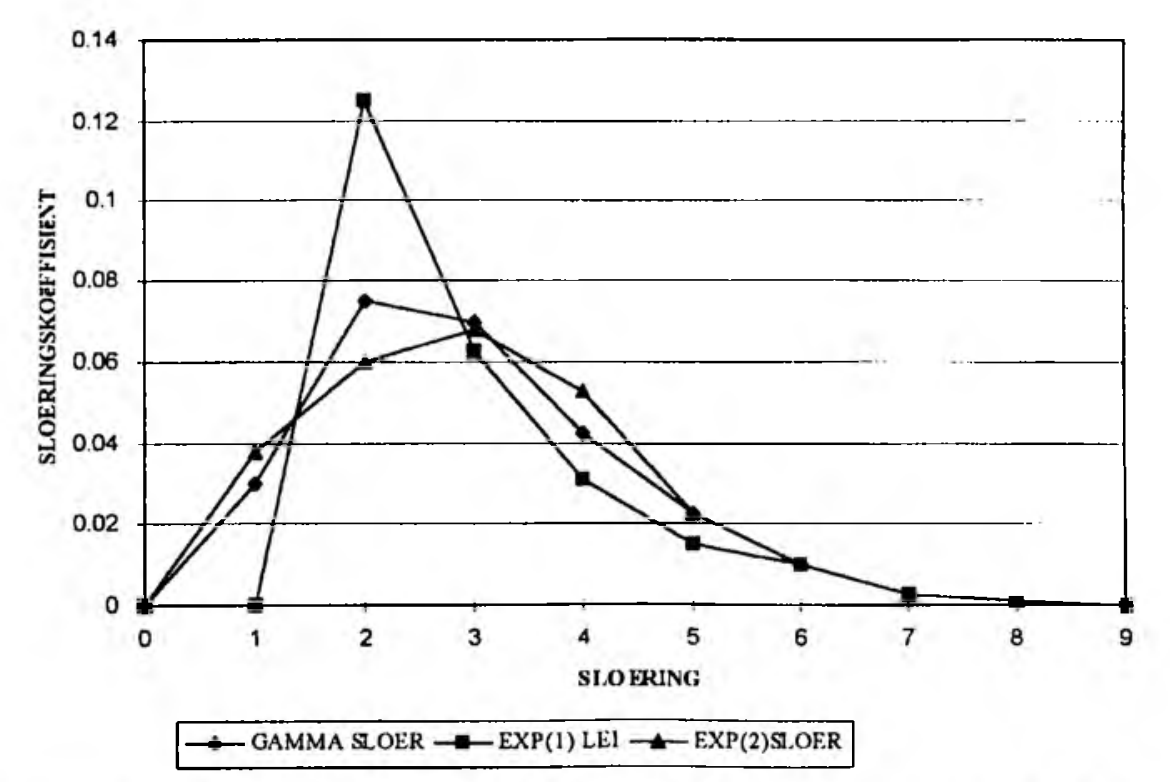

FIGUUR 3: Sloeringseffek van N\&O op totale faktorproduktiwiteit in die SuidAfrikaanse landbou (jaar.) inflasionistiese toestande 'n aanvang geneem. Insetpryse het vinniger as produkpryse gestyg en 'n koste-knyptang is ondervind. ${ }^{17}$ Die koste-knyptang het duidelik buitengewone druk op inkome en die koopkrag van landbouprodusente. ${ }^{1.18}$ Die periode wat nodig is vir die netto inkome van boerderye on negatief te raak, is 'n funksie van die verskil tussen die koerse in stygings lussen inset- en uitsetpryse, asook die oorspronklike marge van inkome bo koste. Met 'n oorspronklike marge van 20 persent en 'n 7,5 persent vinniger styging in inset- as in uitsetpryse sal dit slegs vier jaar neem vir die netto inkome van boerderye om negaticl te raak."

Die strukturele dimensic van die inflasieproses in die SuidAfrikaanse ekonomic is onderliggend tot die bogenoemde problecm van die landbousektor. Alle ingevocrde intermediêre insette en kapitaalgoedere word duurder weens inllasic, maar so ook salarisse en binnelandsgeadministreerde pryse van vervoer en elektrisiteit. Dit het die struktuur van sekondêre industrieè in Suid-Afrika verander. Hulle groci was hoofsaaklik ekstensief, en was gebaseer op die benutting van meer insette ecrder as op hoër produktiwiteit. Invoervervangende groci kon dus slegs deur hoër kosteproduksic volgchou word. Dic verwringende elfek van die stygende koste was versterk deur dic beperking van 'n klein plaaslike mark en die neiging tot monopolisering in die Suid-Afrikaanse ckonomic. Die suksesse van die konserwaticwe regerings in die VSA en Engeland in hulle oorlog teen inflasie in die vroee 1980's het verder gelei tot die verlies van die mededingendheid van Suid-Afrikaanse produkte. ${ }^{\circ}$

Die hoër goudprys in die 1970's, gesamentlik met kostenadele in ander tradisionele uitvoersektore, het Suid-Alrika se afhanklikheid van buitelandse goudverdienstes verhoog. Ekonomicse aktiwiteite was ook gestimuleer. In 1980 het 'n rekordgoudprys gelyktydig met 'n ckonomiese groei van $7,3 \%$ voorgekom. 'n Stygende geldvoorraad het gevolg. Omdat min gedoen was om die groei in besteding te beheer, het die inflasionêre effek van 'n hoë goudprys voortgegaan selfs na die goudprys weer gedaal het. Inflasie het die pryse van industriële insette verhoog. Pryse was verhoog op 'n koste-plus-beginsel, wat die mededingendheid van ingevoerde vervaardigde artikels verhoog het. Tarief- en kwantitatiewe beskerming teen mededinging het addisionele kostes vir dic landbousckior tot gevolg gehad sodat boere se winsmarges drasties verlaag het. Die strukturele verandering wat gelyktydig met die beweging in dic komparaticwe voordeel na steenkool en goud geval het, het 'n negatiewe invloed veral op die landbou gchad. Landbou sou byvoorbeeld onder toestande van 'n tariefvrye handel R22 I miljoen in 1982 gespaar het. ${ }^{20}$

Figuur 4 toon die prysverwantskap in die Suid-Afrikaanse landbou in terme van die ruilvoet (geweegde gemiddelde uitsetpryse gedeel deur die geweegde gemiddelde insetpryse, uitgedruk as ' $n$ indeks). Bogenoemde tendense is duidelik waarneembaar. Dit toon dat dic landbou sedert 1973 oor die algemeen ongunstige bewegings in prysverwantskappe beleef het.

Gegewe hierdie toestande, wat vererger is deur oor die algemeen swak klimaatsomstandighede van die 1980's en vroeë 1990's, het die finansiëlc 
posisie van kommersiële boere drasties verswak. Grootskaalse staatsondersteuning, veral in die vorm van rentesubsidies en markondersteuning, is aan die boerderysektor gegee om wydverspreide bankrotskap die hoof te bied. ${ }^{17}$ Die relaticl' swak prestasie van die Suid-A frikaanse ekonomic, alangehelp deur 'n verskerpte sanksieveldtog teen Suid-Alrikaanse produkte, hel egter veroorsalak dat sodanige hulp onbekostigbalar geword hel. Toenemende internasionale druk vir laer beskermingsvlakke in die vorm van die Algemene Ooreenkoms op Tariewe en I landel (AOTH) wat toe onderhandel is, asook 'n groter beweging na markgerigte produksie in Suid-Afrika, het daartoe bygedra dat staatsondersicuning aan landbou in heroẻnskou geneem is.

Die gevolg was dat staatsondersteuning aan boere in dic jongste verlede drasties afgeneem het. Die produsente-subsidicekwavilent (PSE) het byvoorbeeld gedurende die laat 1980's en vroee 1990's in die meeste gevalle minder as 15 persent beloop teenoor PSE's van meer as 35 persent in ledelande van die Europese Gemeenskap, Skandinawië, dic VSA en Japan (kyk figuur 5). ${ }^{21}$ Beskerming wat landbou-insetverskalliers geniet, en waarvoor dic landbou moct belaal in die vorm van hoër insetpryse, is nic by hierdie lac PSE's vir Suid-Alrika in berekening gebring nie. Verskeic kenners is egter van mening dat indien dit wel gedoen word, dan gevind sal word dat landbou effekticf belas word (hocwel nic betckenisvol nic).

Die vinniger styging van Suid-Afrikaanse inselpryse relatief tol dié van buitelandse lande verswak die mededingendheid van die Suid-Afrikianse uitvoergeoriënteerde boer, met die gevolg dat sy inkomste verminder. ${ }^{5,22}$ Bykomend tot bogenoemde gaan uitvoere gewoonlik na marke waar owerheidsinmenging redelik algemeen is. Die gevolg is dat die landbouruilvoet van SuidAlrikaanse produkte nie net verswak relaticl tot insetpryse nic (figuur 4), maar ook relatief tot die van ander lande. Indien die verskynsel algemeen is vir dic grootste gedeclte van dic uitvocrsektore, mag wisselkocrsveranderings hierdic probleme oorkom. Dic bydrac van dic landbousektor tot dic ekonomic, en spesifick uitvocre, is egter te klein om sodanige korreksies outomaties te laat plaasvind. ${ }^{1 k}$ Gesien teen hierdic agtergrond is die potensiêle effek van internasionale laktore, insluitende wisselkoersveranderings, van groot belang vir die mededingendheid, oorlewing en voortbestaan van die Suid-Alrikanse landbou.

\section{I Algemene internasionale fakore}

Daar word algemeen aanvaar dat veral vier faktore wêreldhandel in landbouprodukte negalief beinvloed en gedestabiliseer het, naamlik: (1) daar was 'n dramatiese verhoging in die athanklikheid van wêreldhandel; (2) 'n goed geïnlegreerde internatsionale kapitaalmark het ontwikkel; (3) sedert 1974 het al meer lande van swewende wisselkoerse gebruik gemaak, sodat veranderings in monetêre beleid toenemend gereflekteer word in 'n land se handelsektore; $\mathrm{en}$ (4) binne hierdie raamwerk was daar' $n$ verhoging in internasionale monetêre onstabiliteit sedert 1986. ${ }^{21}$ Buitelandse verhoudings word gevolglik al meer kompleks, en 'n hersiene teoric van komparatiewe teoric en mededinging is nou nodig - een wat wisselkoerse en monetêre laktore, wat dikwels polities bepaal word, insluit.

Iliermec saam het Suid-Afrika se onderskrywing van dic Algemene Ooreenkoms van Tariewe en Ilandel (AOTII) se Uruguay-rondte wat in 1994 onderteken is en die wegheweeg van 'n beleid van voedselselfvoorsienendheid na voedselsekuriteit in Suid-Alrika soos uiteengesit in dic nuwe Witskrif vir Landboubeleid van 1995, grool implikasies vir die landbousektor en landbouhandel in dic algemeen. Die wegdoen met kwantitatiewe beskerming ten gunste van tariewe wat oor tyd algeskaal moet word - tesame met ander vorms van ondersteuning aan die landbou - verlaag die eflekliewe beskerming van die landbousektor teen buitelandse mededinging. ${ }^{21} \mathrm{Dit}$ bring ook mee dat groter mededinging 'n werklikheid is en dat internasionale faktore, wal deur middel van dic wisselkoers oorgedra word na plaaslike marke, benewens produkliwiteitsaspekte, van dic belangrikste invloede op die mededingendheid van Suid-Afrika se landbouscktor het.

Nieteenstaande hicrdie groter markgerigtheid en konsentrasie op komparaticwe voordeel in produksie, gee die relaticwe grool afstande vanal uitvoerders van veral lywige produkte soos grane en ander stapelvoedsels Suid-A rika se produsente 'n male van beweegruimte ten opsigte van produksie vir die binnelandse mark. Hierdic hoë vervoerkostes ontmoedig egter uitvoere. Die gevolg is dat daar relatief groot verskille tussen die uitvoerrealisasie en invoerpariteit van produkte soos miclies en koring is. Suid-Afrikaanse produsente is dus steeds relatiel geïsoleer wat dic binnelandse mark aanbetref $e n$ is veral hier besonder mededingend vanweè hul liggingsvoordeel. Ten opsigte van uitvoere geld die teenoorgestelde egter.

Dic elfek van dic wisselkocrs op internasionale mededinging is deurslaggewend. 'n Oorgewaardeerde wisselkoers maak invoere goedkoper relatief tot plaaslike produkle, lerwyl 'n ondergewaardecrde wisselkoers die teenoorgestelde effek hel. Die resultaat wen of verloor - word egter bepaal deur wat met winggewendheid gebeur: is die styging (daling) in inkomsic genoeg om te kompenseer vir dic styging (afname) in kostes?

\subsection{Effek van wisselkoersver- anderings op insetpryse}

Die effek wat wisselkoersveranderings histories op die prys van verskillende insetkategorieë uitoefen, is reeds vroeër ontlecd. ${ }^{24}$ 
Tabel I gee sommige van die resultate wat in hierdie verband verkry is, naamlik (1) die variasie van verskillende insetpryse wat verklaar word deur veranderings in wisselkoerse; en (2) dic effek van 'n eenpersentverandering in die wisselkoers op verskillende insetpryse.

Volgens tabel I verklaar veranderings in die wisselkoers minder as 60 persent van die prysvariasie in die meeste insetkategorieë. ' $n$ Eenpersentverswakking van die effektiewe Rand-wisselkoers lei tol 'n styging van tussen 0,2 en 0,7 persent in die pryse van insette. Slegs die prys van trekkers word reeds binne die ecrste dric maande na dic verswakking van dic wisselkoers beinvloed. Dic effek van wisselkoerse op ander insetpryse vind gewoonlik plaas van vier tot nege maande na die verswakking in die wisselkoers plaasgevind het. Die sylers beklemtoon die relatief groot effek van wisselkoerse op die insetprysveranderings. Trekker-en brandstolpryse verhoog byvoorbecld met 0,7 persent na 'n verswakking van 1,0 persent in die wisselkoers plaasgevind het. Die effek is baie kleiner op boumateriaal $(0,3$ persent) en vragmotors $(0,31$ persent $)$.

Dic relatief groot effek van wisselkoersveranderings op spoorvragkoste is kommerwekkend. Dit is duidelik waarom dic wisselkoers pryse van brandstof beinvloed aangesien dit ingevoer word. Dit is egter nie duidelik waarom dieselfde met spoorwegkostes gebeur nie. Die afwesigheid van effekticwe mededinging mag moontlik deels hiertoe bydra. Die hoë vervoerkostes dra by tol die effektiewe isolering van die binnelandse mark teen buitelandse mededinging, veral vir lywige

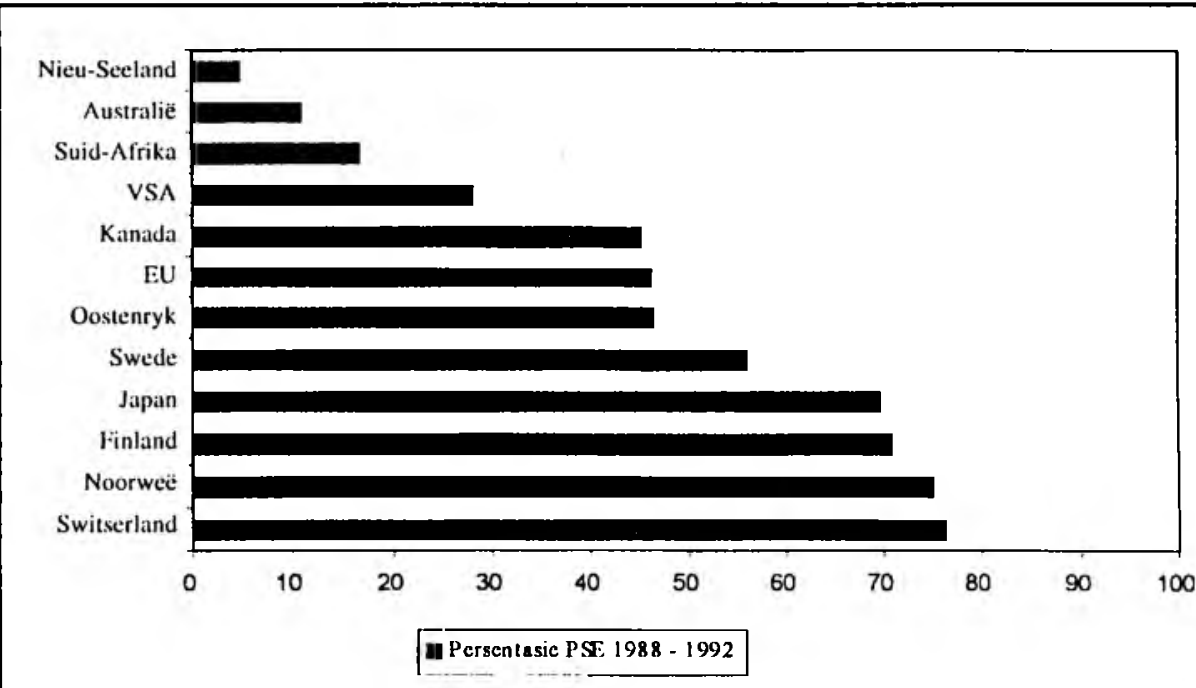

FIGUUR 5: Gemiddelde persentasie produsentesubsidie-ekwivalent (PSE). (1988-1993). produkte. Soos reeds opgemerk, werk dit egter ook negatief in op uitvocre.

\subsection{Effek van wisselkoersveranderings op mededingendheid}

Uit die vorige afdeling is dit duidelik dat wisselkoersveranderings die produksiekoste en winsgewendheid van ' $n$ landboubedrylstak, en dus ook mededingingsvermoë, beinvloed. Om die effek van hierdie veranderings in die wisselkoers te meet, is redelik maklik wanneer die inligting in tabel 1 gebruik word (die syfers is egter slegs van toepassing wanneer die wisselkoers daal - ondervinding het geleer dat insetpryse nic noodwendig daal wanneer die wisselkoers weer versterk nic). Die effek daarvan op inkome is ook redelik maklik om te bepaal: uit vocrverdienstes styg in direkte verhouding mel die verandering in die wisselkoers, terwyl binnelandse inkomstes nic direk beinvloed word nie. Invoere word egter direk duurder - dit bied dus dieselfde indirekte voordeel asof alles uitgevoer word.

'n Algemene verswakking in die wisselkoers, soos wat onlangs belect is, verhoog gevolglik dic landbouscktor se mededingendheid drasties teenoor mededingers van buite die Rand se monetêre gebied.

\section{GEVOLGTREKKING}

Die Suid-Afrikaanse landbouscktor het gedurende die 1980's en vroeë 1990's swaar gekry as gevolg van ongunstige prysverwantskappe met inselpryse wat oor die algemeen vinniger gestyg het as pryse van landbouprodukte. Die negatiewe invloed van hierdic tendense is teengewerk deur ansienlike stygings in totale laktorproduktiwiteitsgroei, veral sedert 1983. Die gevolg van hierdie twee teenoorgestelde kragte was dat rec̈le netto boerdery-inkomste relaticf konstant gebly het oor die hele periode (met groot jaarlikse skommelings te wyte aan droogte). Die tendense hou nou verband met die verwringings wat grootliks veroorsaak is deur landboubeleid, algemene ekonomiese beleid en handelsbeleid.

Die toename in TFP in die laat 1980's en 1990's het die wêreld-

TABEL 1 Effek van wisselkoersveranderings op landbou-insetpryse $\mathrm{e}^{24}$

\begin{tabular}{|l|c|c|}
\hline Insetkategorieë & $\begin{array}{c}\text { Insetprysverandering verklaar } \\
\text { deur verandering in die wisselkoers } \\
(\%)\end{array}$ & $\begin{array}{c}\text { Effek van 'n 1\%-verandering in die } \\
\text { effektiewe wisselkoers op insetpryse } \\
(\%)\end{array}$ \\
\hline Trekkers & 64,3 & 0,690 \\
Vragmotors & 44,3 & 0,314 \\
Implemente & 47,9 & 0,343 \\
Besproeiingstoerusting & 27,1 & 0,708 \\
Vaste verbeterings & 36,6 & 0,291 \\
Kunsmis & 17,8 & 0,492 \\
Brandstof & 18,3 & 0,698 \\
Verpakkingsmateriaal & 27,5 & 0,632 \\
Onderhoud en herstel & 46,4 & 0,448 \\
Spoorvrag & 39,9 & 0,408 \\
\hline
\end{tabular}


mededingendheid van dic Suid-Alrikanse landbou verslerk gedurende 'n periode waar ondersteuning en beskerming aan die sektor aansienlik verminder is. Trouens, grootskaalse bankrotskappe onder kommersiële boere sou aan die orde van die dag gewees het as dit nic hicrvoor was nie. Landbounavorsing hel' $n$ belangrike rol gespeel in die loename in produktiwitcit. Die interne opbrengskoers van openbare besteding aan landbounavorsing is bereken op 44 persent per jaar. Dit dien as motivering vir die behoud en uithou van landbounavorsing met behulp van openbare fondse.

Hiertenoor hel dic relatiel' sterk wisselkoers, gepaardgaande met die wegdoen van kwantitatiewe beskerming ten gunste van larifering, Suid-Afrikaanse landbouprodusente minder mededingend gemaak. Hoë vervoerkoste, veral na Gauteng, help egter om die binnelandse marke tot 'n mate te "isoleer" teen buitelandse mededinging, spesifiek vir lywige grane soos mielies en koring. Hierdie aspek beïnvloed uilvoere egter nadelig.

Die onlangse algemene en skerp verswakkings in die wisselkoers bring wesentlike verbelerings in die prysverwantskappe van plaaslike landbouprodukte. Dit maak invoere prysgewys aansienlik minder aantreklik, en verhoog dic uilvoerrealisasic van Suid-Afrikaanse uitvoere. Die internasionale mededingendheid van dic landbousektor is dus aansienlik verhoog.

Die algemene gevolgtrekking is dus dat die landbousektor as geheel vandag miskien armer en maerder daar uitsien as in die sewentigerjare, maar dat dit heclwat fikser is en in 'n uitstekende posisie is om by le dra tol die uitdagings van hoër ckonomiese groei. Beide produktiwiteit en prysverwantskappe bewecg in 'n gunstige rigting, met die gevolg dat die Suid-Afrikaanse kommersiële landbousektor se wêreldmededingendheid hoog is. In teenstelling met die nywerheid kan slegs 'n klein minderheid landbouprodukte goedkoper ingevoer word as waarvoor Suid-Afrikaanse produsente dit kan produseer, al word alle beskerming opgehef en ten spyte van relatief groot ondersteuning aan produsente in die meeste ontwikkelde lande. Die vooruitsigte vir die Suid-Alrikaanse landbou is gevolglik uitstekend.

\section{SuMMARY}

Changes in productivity are inlluenced by two clearly distinguishable and measurable components, namely change in capacity utilisation and change in efficiency. The increase in total factor productivity (TFP) in South African agriculture has been relatively low over the past five decades: approximately 1,4 pereent per year. However, it is clear that there was no TFP growth over the period 1947-65. During the period 1965-8I TFP increased al a rate of 2,15 pereent per year, while the growth rate has since increased to almost 3,0 percent per year. The underlying reasons for the change in TFP in the South Alrican commercial agriculture are explained on the basis of unconventional inputs such as local research and development (R\&D), overflow eflects of overseas R\&D, extension, training and climate.

The South African agricultural sector suffered during the 1980 's and the carly 1990's as a result of unfavourable price relations with input prices generally increasing laster than the prices of agricultural products. The negative influence of these trends was offset by considerable increases in tolal factor produclivity growlh, particularly since 1983. The result of these two opposing forces was that real nett farm income remained relatively consistent since 1960 (with large annual fluctuations due to drought). The trends are closely related to distortions caused by agricultural policy, general economic policy and trade policy.
The increase in 'TFP in the late 1980's and 1990's has improved the world competitiveness of South African agriculture during a period in which support and protection for the sector were considerably reduced. In fact, large scale bankruptcy would have been prevalent amongst commercial farmers if it were not for this. Agricultural research has played an important role in the increase in produclivity. The internal rate of return on public agricultural research spending is calculated at 44 percent per year. This serves as motivation for retaining and expanding agricultural research with the aid of public funds.

Opposed to this, the relatively strong exchange rate. together with the disposal of quantitative protection in favour of setting tariffs, reduced the competitiveness of South African agricultural producers. However, high transport costs, particularly to Gatuteng, contribute to the isolation of the internal markets against foreign competition to a degree, specifically with regard to staple grains such as maize and wheat. However, this aspect has a negative influence on exports.

The recent general and sharp weakening in the exchange rate causes improvements in the price relations of local agricultural products. Price-wise this makes imports considerably less attractive and increases the export realisation of South African exports. Thus, the international competitiveness of the agricultural sector has increased considerably.

The general conclusion is that the agricultural sector as a whole may seem poorer and leaner today than in the seventies, but that it is in fact much fitter and in an excellent position to contribute to the challenges of higher economic growth. Both productivity and price relations are following a favourable trend, resulting in increasing compelitiveness for South African agriculture. In contrast to industry, only a small minority of agricultural products can be introduced locally at a cost lower than South African production costs, even il all protection is lifted and despite relatively extensive support given to producers in most developed countries. Consequently, the prospects for the South African agriculture are excellent.

\section{IJITERATUURVERWYSINGS}

1. Van Zyl, J. \& Groenewald, J.A. (1988). The Effects of Protection on South African Commercial Agriculture, Journal of Agriculrural Economics, 39(3), 387-401.

2. Wêreldbank (1994). South African Agriculture: Structure, Performance and Options for the Future, Discussion Paper on Aspects of the Economy of Sourh Africa No. 6. Southern Alrica Department. World Bank, Washington, D.C.

3. Van Zyl, J. (1995). The Relationship Between Farm Size and E(ficiency in South African Commercial Agriculture, Agrekon, 34(4), 93-104.

4. Groencwald, J.A. (1982). Changes in the parity position of South African Agriculture, Agrekon, 2 ! (2), 8-14

5. Groenewald, J.A. (1985). The South African Agriculture and Inflation Phenomena, Agrekon, 24(1), 30-36.

6. Van Zyl, J. \& Van Rooyen, C.J. (1990), Agricultural Production in South Africa: An Overvicw. In: A Harvest of Discontent: The land Question in South Africa, De Klerk, M. (ed.) (IDASA, Cape Town).

7. Jacobskomitce (1983). Ondersoek oor die langtermynlewensiat barnheid van die mieliebedryf, Verslag van dic Workskomitec Insake die Finansiële Posisic van dic Boer en Landboufinansiering in dic Algemeen, Staatsdrukkery, Pretoria.

8. Bochlje, M.D. \& Eidman, V.R. (1984). Farm Managememr (John Wiley and Sons, New York).

9. Echeverria, R. (cd.) (1990). Methods for Diagnosing Research System Constraints and Assessing the Impact of Agricultural Research. ISNAR, The Hague.

10. Evenson, R.E., Landau, D. \& Ballou, D. (1987). Agricultural Productivity Measures for US States, Proceedings of a Symposium. Miscellaneous Publication 52-1987, Landbounavorsingstasic, 
Universiteit van Minnesota, St. Paul.

11. Thirtle, C.. Sartorius von Bach. H. \& Van Zyl, J. (1993). Total Factor Productivity in South African Agriculture. 1947-91. Delelopment Southern Africa, 10(3), 301-317.

12. Thirtle, C. \& Van Zyl, J. (1994). Explaining TFP Growlh in South Africa: The Retums to R\&D and Exicnsion, South African Jourmal of Agriculmural Litension. 23, 35-4l.

13. Khalti, Y.J., Thirtle, C. \& Van Zyl. J. (1996). The Rate of Return to Agricullural Research in Somin Africa: The Tivo-Stage Apmoach. Ongepubliseerde Navorsingsverslag, Universiteit van Pretoria.

14. Groenewald, J.A. (1964). Changes in Primary Resources in the South African Agriculture, Agrekon, 3(3), 22-29.

15. Sartorius von Bach, H.J. \& Van Zyl. J. (1991). Have recent Structural Changes Caused Agriculture to become Less Rigidl? Developmem Soulhern Africa, 8(3), 399-4()4.

16. Van Zyl, J., Fényes, T.I. \& Vink, N. (1987), Labour-related Structural Trends in South African Maize Production, Agricultural Leconomics, 1(3), 241-258.
17. Van Zyl, J. (1990). The Effects of Inflation on Agricultural Produc(ion under Conditions of Risk, Agreken, 25(3), 52-59.

18. Van Zyl, J. (1986). Duality and Elasticities of Substitution II: An Empirical Application, Agrekom, 25(3), 6.5-69.

19. Louw, A. (1981). Business growth in Agriculture III: The effect of inflation on business growth, Agrekon, 20(1), 1-15.

20. Bepa (1983). Die koste, wordele en finansiering ban beskerming in Suid-Afrika: Die insloed ran beskerming op die landbon, Navorsingsverslag Nr. 17, Universiteit van Preloria, Pretoria.

21. Helm, W. \& Van Zyl, J. (1994). Quantifying agricultural supporl in South Africa, Agrekom, 33(4), 152-163.

22. Liebenberg. G.F. (1990). Imiloed l'an Wisse/koerse op die uitvoerdienste van die RSA-landbou, Ongepublisecrde M.Sc. (Agric.)verhandeling, Universiteit van Pretoria, Pretoria.

23. Schuh, G.E. (1985). Stralegic Issues in World Agriculume (Wêreldbank. Washington, D.C).

24. Liebenberg, G.F. \& Groenewald, J.A. (1991). Die RSA Landbouruilvoct, Agrekom, 29(3), 178-184. 